\title{
PHOSPHORUS LEACHING IN SOILS AMENDED WITH PIGGERY EFFLUENT OR LIME RESIDUES FROM EFFLUENT TREATMENT
}

\author{
D. M. Weaver \& G. S. P. Ritchie
}

\begin{abstract}
Phosphorus $(P)$ in wastes from piggeries may contribute to the eutrophication of waterways if not disposed of appropriately. Phosphorus leaching, from three soils with different $P$ sorption characteristics (two with low $P$ retention and one with moderate $P$ retention) when treated with piggery effluent (with or without struvite), was investigated using batch and leaching experiments. The leaching of $P$ retained in soil from the application of struvite effluent was determined. In addition, $P$ leaching from lime residues (resulting from the treatment of piggery effluent with lime to remove $P$ ) was determined in comparison to superphosphate when applied to the same three soils.

Most $P$ was leached from sandy soils with low $P$ retention when effluent with or without struvite was applied. More than $100 \%$ of the filterable $P$ applied in struvite effluent was leached in sandy soils with low $P$ retention. Solid, inorganic forms of $P$ (struvite) became soluble and potentially leachable at $\mathrm{pH}<7$ or were sorbed after dissolution if there were sufficient sorption sites. In sandy soils with low $P$ retention, more than $39 \%$ of the total filterable $P$ applied in recycled effluent (without struvite) was leached. Soil $P$ increased mainly in surface layers after treatment with effluent. Sandy soils pre-treated with struvite effluent leached $40 \%$ of the $P$ retained in the previous application. Phosphorus decreased in surface layers and increased at depth in the soil with moderate $P$ retention after leaching the struvite effluent pre-treated soil with water. The soils capacity to adsorb $P$ and the soil $\mathrm{pH}$ were the major soil properties that affected the rate and amount of $P$ leaching, whereas the important characteristics of the effluent were $p H, P$ concentration and the forms of $P$ in the effluent.

Phosphorus losses from soils amended with hydrated lime and lime kiln dust residues were much lower than losses from soils amended with superphosphate. Up to $92 \%$ of the $P$ applied as superphosphate was leached from sandy soils with low $P$ retention, whereas only up to
\end{abstract}

$60 \%$ of the $P$ applied in lime residues was leached. The $P$ source contributing least to $P$ leaching was the lime kiln dust residue. The amount of $P$ leached depended on the water-soluble $P$ content, neutralising value and application rate of the $P$ source, and the $p H$ and $P$ sorption capacity of the soil.

Keywords: phosphorus, leaching, lime residue, piggery effluent, struvite.

\section{INTRODUCTION}

Phosphorus (P) loss from soils by leaching or runoff contributes to the eutrophication of waterways (Sas, 1989). Nutrients contributing to eutrophication have their source in fertilisers applied to agricultural land, industrial wastewaters, or intensive rural industries, such as piggeries (Raper, 1983). A single piggery, for example, contributes about $10 \%$ of the total $\mathrm{P}$ load to the Peel-Harvey estuarine system in Western Australia (Humphries \& Bott, 1987).

Pollution from piggeries may arise because common methods of effluent disposal include spray irrigation or discharge to waterways after settling in ponds. Unfortunately, these methods do not always remove sufficient $P$ to prevent eutrophication, particularly if the effluent is irrigated onto soils which have a low sorption capacity for $P$.

Lime and bauxite residues have been used to remove P from effluent (Weaver \& Ritchie, 1987, 1993). Lime treatment can decrease the $\mathrm{P}$ concentration of effluent so that it is less likely to enrich waterways with nutrients. The waste sludge (lime residue) resulting from lime dosing of effluent also requires disposal. Possible disposal methods include its use as a source of $\mathbf{P}$ for plants or to ameliorate acidic soils. In either case, the use of this material may be constrained by its $P$ leaching characteristics.

The quantity of $P$ leached from soil when effluent or lime residues are applied will depend on the forms of $\mathbf{P}$ in the source material, $\mathrm{P}$ application rate, the $\mathrm{P}$ sorption characteristics and $\mathrm{pH}$ of the soil, and $\mathrm{P}$ uptake by plants. Both effluents (Payne, 1986) and soils have widely different properties that may affect $\mathrm{P}$ losses. In 
addition, effluent properties are continually changing as producers cut costs by conserving water and recycling the effluent.

The objectives were to study the effect of the forms of $\mathbf{P}$ in piggery effluent on $\mathbf{P}$ losses from three soils, and to ascertain whether $P$ retained from the application of effluent was subsequently leached. Also, P losses from three soils were compared when superphosphate or lime residues from effluent treatment were applied at rates adequate for maximum growth of clover or medic pasture species.

\section{MATERIALS AND METHODS}

\section{Experiment 1-Addition of piggery effluent or ortho- phosphate to soils}

Phosphorus remaining in solution was determined when piggery effluent or an inorganic, soluble source of $\mathrm{P}\left(\mathrm{K}_{2} \mathrm{HPO}_{4}\right)$ was mixed with three soils of different $\mathrm{P}$ sorption capacities at six solution: soil ratios.

Piggery effluent was collected from the outflow of the last of three anaerobic ponds at a piggery housing 22000 pigs and producing $4 \times 10^{8}$ litres of effluent annually. The effluent was frozen in 1 litre portions and thawed as required (Weaver \& Ritchie, 1987). It contained $41 \mathrm{mg}$ litre ${ }^{1}$ total P (TP), $17.5 \mathrm{mg}^{\text {litre }}{ }^{-1}$ filterable P (P determined on effluent filtered through a $0.45 \mu \mathrm{m}$ membrane filter), had a $\mathrm{pH}$ of 8.0 , and had some $\mathrm{P}$ as suspended particles (struvite, $\mathrm{NH}_{4} \mathrm{MgPO}_{4} \cdot 6 \mathrm{H}_{2} \mathrm{O}$, confirmed by $\mathrm{X}$-ray diffraction). The ortho-phosphate solution had a $\mathrm{P}$ concentration of $23.9 \mathrm{mg}$ litre ${ }^{1}$ and was prepared from $\mathrm{K}_{2} \mathrm{HPO}_{4}$, so that the $\mathrm{pH}(7 \cdot 7)$ was close to that of the effluent.

Soils used in the study have been described by Bettenay et al. (1960; Joel and Coolup soils) and by Mulcahy (1960; Balkuling soil). Relevant soil properties are in Table 1.

Each soil $(<2 \mathrm{~mm})$ was shaken end over end for $16 \mathrm{~h}$ with the struvite effluent or the ortho-phosphate solution at solution: soil ratios of $1.25: 1(\mathrm{ml}: \mathrm{g}), 5: 1,12.5: 1$, $25: 1,37 \cdot 5: 1$ and $50: 1$ in duplicate. Each sample was centrifuged and filtered $(<0.45 \mu \mathrm{m})$. Filterable $\mathrm{P}$ and $\mathrm{pH}$ were determined on the filtered supernatant (John, 1970).

\section{Experiment 2-Leaching of $P$ from soils amended with piggery effluent}

The aim of this experiment was to compare $\mathbf{P}$ loss from soils with different $P$ sorption capacities when piggery effluent, with or without struvite, was applied, and to compare $\mathbf{P}$ loss from soils that had already been treated with struvite effluent.

The struvite effluent contained $40.4 \mathrm{mg}$ litre ${ }^{-1} \mathrm{TP}$ and $15.8 \mathrm{mg} \mathrm{litre}^{-1}$ filterable P. The effluent with no struvite was collected from a piggery that recycled effluent as part of its daily waste management activities. The effluent with no struvite contained 240 and $190 \mathrm{mg} \mathrm{litre}^{-1}$ of TP and filterable $\mathrm{P}$, respectively.

Duplicate columns $(10 \mathrm{~cm}$ depth, $9.4 \mathrm{~cm}$ inside diameter) of three soils (Balkuling, Coolup and Joel) were leached with $\sim 5000 \mathrm{ml}$ of struvite effluent or with $\sim 700 \mathrm{ml}$ of effluent with no struvite. In the latter case
Table 1. Some physico-chemical properties of the soils

\begin{tabular}{|c|c|c|c|}
\hline \multirow[t]{2}{*}{ Soil property } & \multicolumn{3}{|c|}{ Soil } \\
\hline & Joel & Coolup & Balkuling \\
\hline Northcote classification ${ }^{a}$ & Uc $2 \cdot 33$ & Dy 5.71 & Dy 5.51 \\
\hline Bulk density $\left(\mathrm{g} \mathrm{cm}^{-3)}\right)$ & 1.29 & 1.76 & $1 \cdot 30$ \\
\hline Organic carbon $(\%)^{b}$ & $3 \cdot 5$ & 0.5 & $3 \cdot 1$ \\
\hline $\mathrm{pH}(1: 5$, water $)$ & $5 \cdot 2$ & $5 \cdot 5$ & $6 \cdot 2$ \\
\hline $\mathrm{pH}\left(1: 5,0.0017 \mathrm{M} \mathrm{CaCl}_{2}\right)$ & 4.0 & $4 \cdot 2$ & $5 \cdot 4$ \\
\hline Conductivity, $1: 5$ water $(\mu \mathrm{S} \mathrm{cm}$ & ) 35 & 28 & 115 \\
\hline TP $\left(\mu \mathrm{g} \mathrm{g}^{-1}\right)^{c}$ & 13.8 & $8 \cdot 9$ & $101 \cdot 2$ \\
\hline Inorganic $\mathbf{P}\left(\mu \mathrm{g} \mathrm{g}^{-1}\right)^{c}$ & 2.6 & $2 \cdot 0$ & $23 \cdot 5$ \\
\hline Organic $\mathrm{P}\left(\mu \mathrm{g} \mathrm{g}^{-9}\right)^{c^{\prime}}$ & $11 \cdot 2$ & $6 \cdot 9$ & $77 \cdot 7$ \\
\hline Bicarbonate $\mathrm{P}\left(\mu \mathrm{g} \mathrm{g}^{-1}\right)^{d}$ & $3 \cdot 0$ & $1 \cdot 6$ & $8 \cdot 1$ \\
\hline Phosphorus retention index ${ }^{e}$ & $0 \cdot 31$ & $1 \cdot 5$ & 48 \\
\hline $\mathrm{Ca}\left(\mathrm{cmol}_{\mathrm{c}} \mathrm{kg}^{-1}\right)^{f}$ & $3 \cdot 3$ & 0.5 & $3 \cdot 8$ \\
\hline $\mathrm{Mg}\left(\mathrm{cmol}_{\mathrm{c}} \mathrm{kg}^{-1}\right)^{f}$ & 0.18 & $0 \cdot 14$ & 0.16 \\
\hline Sand $(\%)$ & 90.8 & 93.4 & 73.8 \\
\hline Silt $(\%)$ & $2 \cdot 0$ & 1.9 & $7 \cdot 6$ \\
\hline Clay $(\%)$ & $7 \cdot 2$ & 4.7 & $18 \cdot 6$ \\
\hline $\mathrm{Fe}(\%)^{g}$ & 0.002 & 0.01 & 0.035 \\
\hline $\mathrm{Al}(\%)^{g}$ & 0.003 & 0.01 & $0 \cdot 24$ \\
\hline
\end{tabular}

a Northcote (1979).

${ }^{b}$ Sims and Haby (1971).

'Saunders and Williams (1955).

${ }^{d}$ Colwell (1963).

e Allen and Jeffery (1990).

$f$ Thomas (1982).

${ }^{g}$ Searle and Daly (1977).

lower volumes of effluent were applied because permeability of the soil was reduced due to the greater total solids content of the recycled effluent. Leachates from the application of struvite effluent were analysed for filterable $\mathrm{P}$ and $\mathrm{pH}$, while those from the application of effluent with no struvite were analysed for total filterable P (TP of sample filtered through a $0.45 \mu \mathrm{m}$ filter). One replicate of the soil columns treated with struvite effluent was removed at the end of the leaching phase, sectioned into $0-1,1-2,2-4,4-6,6-8$ and $8-10 \mathrm{~cm}$ increments and dried at $50^{\circ} \mathrm{C}$ for $24 \mathrm{~h}$ for analysis. The other replicate was leached with $\sim 5000 \mathrm{ml}$ of distilled water. Leachates and depth increments of the soil column were retained for analysis as before. Sectioned soil samples were analysed for electrical conductivity, $\mathrm{pH}$ and filterable $\mathrm{P}$ in a 1:5 water extract (extractable filterable P), bicarbonate extractable P (Colwell, 1963), and total, inorganic and organic $\mathrm{P}$ (Saunders \& Williams, 1955). Phosphorus was determined using the method of John (1970) or Hanson (1950) depending on concentration. Effluent and leachate samples were digested with perchloric acid (AOAC, 1984).

A qualitative assessment of the rate at which $\mathrm{P}$ was leached from each soil was made by observing how the $P$ concentration and the slope of the relationship between cumulative $\mathbf{P}$ leached versus cumulative leachate volume changed as leaching progressed.

Experiment 3-Leaching of $P$ from soils amended with lime residues

Phosphorus loss was compared from three soils amended with two types of lime residues or super- 
Table 2. Some properties of the $P$ sources

\begin{tabular}{lcccc}
\hline P source & TP & $\begin{array}{c}\text { Water- } \\
\text { soluble P }\end{array}$ & $\begin{array}{c}\text { Citrate- } \\
\text { soluble P } \\
(\% \text { of TP })\end{array}$ & $\begin{array}{c}\text { Neutralising } \\
\text { value }\end{array}$ \\
\hline $\begin{array}{l}\text { Superphosphate } \\
(\%)\end{array}$ & $9 \cdot 1$ & 84 & 9 & ND $^{a}$ \\
12 \\
$\begin{array}{l}\text { Hydrated lime } \\
\text { residue }\end{array}$ & $1 \cdot 1$ & 2.9 & ND & 12 \\
$\begin{array}{l}\text { Lime kiln dust } \\
\text { residue }\end{array}$ & $0 \cdot 8$ & 0.1 & ND & 29 \\
\hline
\end{tabular}

"ND-not determined.

phosphate. The lime residues were produced as a result of the treatment of piggery effluent for $\mathrm{P}$ removal and were obtained using the method outlined in Weaver and Ritchie (1994). Total P, water-soluble $P$ and the neutralising value of the lime residues were determined using standard procedures outlined by AOAC (1984).

Duplicate columns $(10 \mathrm{~cm}$ depth, $9.4 \mathrm{~cm}$ inside diameter) were packed with soil to field bulk density and either superphosphate, hydrated lime residue or lime kiln dust residue (Table 2) was mixed into the top $1 \mathrm{~cm}$ of soil. Phosphorus was applied at rates equivalent to 10,80 and $640 \mathrm{~kg} \mathrm{ha}^{-1}$ for the Joel, Coolup and Balkuling soils, respectively. These rates were determined from glasshouse experiments that estimated the $P$ requirement for maximum growth of sub-clover or medic species. Each column was leached with $\sim 5000 \mathrm{ml}$ of deionised water. Subsamples of leachates were retained for analysis. Filterable P of the leachates was determined as before.

\section{RESULTS}

\section{Experiment 1-Addition of piggery effluent or ortho-} phosphate to soils

$\mathrm{pH}$ increased as the amount of effluent or $\mathrm{P}$ solution mixed with each soil increased. At a constant level of addition of effluent or $\mathbf{P}$ solution, $\mathrm{pH}$ increased in the order Joel < Balkuling < Coolup. Filterable $\mathrm{P}$ increased with increasing effluent:soil ratio for the Balkuling soil and decreased for the Joel and Coolup soils. Filterable $P$ was higher than the original effluent filterable $P$ at each ratio for the Joel and Coolup soils. This occurred in the Balkuling soil when the effluent: soil ratio exceeded 37.5:1 (Table 3).

When the Coolup and Balkuling soils were mixed with ortho-phosphate solutions, filterable $\mathrm{P}$ was lower than the initial filterable $\mathrm{P}$ and increased as the $\mathrm{P}$ solution : soil ratio increased. For the Joel soil, filterable $P$ was higher than the initial filterable $P$ when the $P$ solution: soil ratio was $1 \cdot 25: 1$ and decreased slightly as the ratio increased (Table 3).

Filterable $\mathrm{P}$ was independent of $\mathrm{pH}$ at values $<7$ when effluent was added to soil. At higher $\mathrm{pH}$ values, the filterable $\mathrm{P}$ increased with increasing $\mathrm{pH}$ for the Balkuling soil and decreased with increasing $\mathrm{pH}$ for the Joel and Coolup soils (Table 3).

Filterable $\mathrm{P}$ increased with increasing $\mathrm{pH}$ when
Table 3. pH and filterable $P$ after mixing struvite effluent or ortho-phosphate solutions with soil at different solution : soil ratios

\begin{tabular}{|c|c|c|c|c|c|}
\hline \multirow{2}{*}{ So } & \multirow{2}{*}{$\begin{array}{l}\text { Solution : soil } \\
\text { ratio } \\
(\mathrm{ml}: \mathrm{g})\end{array}$} & \multicolumn{2}{|r|}{$\mathrm{pH}$} & \multicolumn{2}{|c|}{$\begin{array}{r}\text { Filterable } p \\
\left(\mathrm{mg} \mathrm{litre}^{-1}\right)\end{array}$} \\
\hline & & Effluent & P solution & Effluent & $\mathbf{P}$ solution \\
\hline \multirow[t]{6}{*}{ Joel } & 1.25 & $5 \cdot 2$ & 4.4 & $48 \cdot 1$ & $25 \cdot 2$ \\
\hline & 5 & $6 \cdot 5$ & 4.8 & 47.0 & 23.5 \\
\hline & $12 \cdot 5$ & $7 \cdot 0$ & $5 \cdot 1$ & 49.7 & $23 \cdot 3$ \\
\hline & 25 & $7 \cdot 4$ & 5.7 & 41.4 & $22 \cdot 6$ \\
\hline & 37.5 & $7 \cdot 6$ & 5.9 & 38.2 & $22 \cdot 1$ \\
\hline & 50 & $7 \cdot 7$ & $6 \cdot 3$ & $28 \cdot 3$ & $22 \cdot 1$ \\
\hline \multirow[t]{6}{*}{ Balkuling } & 1.25 & $6 \cdot 2$ & $5 \cdot 6$ & $3 \cdot 1$ & $3 \cdot 3$ \\
\hline & 5 & 7.0 & $6 \cdot 1$ & 6.0 & 4.5 \\
\hline & 12.5 & 7.4 & $6 \cdot 4$ & $19 \cdot 5$ & 11.9 \\
\hline & 25 & 7.6 & $6 \cdot 6$ & $14 \cdot 4$ & $16 \cdot 5$ \\
\hline & 37.5 & 7.8 & $6 \cdot 7$ & $20 \cdot 0$ & $19 \cdot 4$ \\
\hline & 50 & $7 \cdot 8$ & $6 \cdot 9$ & $23 \cdot 9$ & $20 \cdot 5$ \\
\hline \multirow[t]{6}{*}{ Coolup } & $1 \cdot 25$ & $7 \cdot 2$ & $5 \cdot 3$ & $26 \cdot 6$ & $19 \cdot 1$ \\
\hline & 5 & 7.7 & 6.0 & $33 \cdot 4$ & $21 \cdot 3$ \\
\hline & 12.5 & 7.9 & 6.7 & 21.7 & 21.9 \\
\hline & 25 & 7.9 & $7 \cdot 0$ & $24 \cdot 1$ & 23.8 \\
\hline & 37.5 & 8.0 & $7 \cdot 2$ & 19.7 & 23.9 \\
\hline & 50 & $8 \cdot 0$ & $7 \cdot 3$ & 19.6 & 23.7 \\
\hline
\end{tabular}

ortho-phosphate was added to the Balkuling and Coolup soils and decreased with increasing $\mathrm{pH}$ for the Joel soil. The change in filterable $\mathrm{P}$ with $\mathrm{pH}$ was much greater for the Balkuling soil than for the Joel and Coolup soils (Table 3 ).

Experiment 2-Leaching of $P$ from soils amended with piggery effluent

Phosphorus in leachates after treating soil with struvite effluent

Filterable $\mathrm{P}$ concentration in leachates of the Joel soil were always greater than the original filterable $\mathrm{P}$ concentration of the effluent. Leachates of the Balkuling soil always had lower filterable $P$ concentrations than originally applied (Fig. 1(a)). The filterable P concentration in the leachate of the Coolup soil was initially lower than the original filterable $P$ concentration of the effluent but increased with increasing leachate volume above that originally in the effluent (Fig. 1(a)).

When soils were treated with struvite effluent, the quantity of filterable $\mathrm{P}$ leached was in the order Joel $>$ Coolup $\gg$ Balkuling (Fig. 2(a)). Only $2 \%$ of the total P added to the Balkuling soil was found in the leachate, whereas $62 \%$ was found in the leachate of the Joel soil (Table 4). Filterable $P$ in the leachate of the Joel soil was $159 \%$ of that applied. In the Balkuling soil, however, only $6 \%$ of the applied filterable $P$ was found in the leachate (Table 4).

The rate at which $P$ leached from the Joel soil was constant over the entire effluent leaching period. The rate of loss of $\mathbf{P}$ from the Coolup soil was constant and similar to the Joel soil after more than $2000 \mathrm{ml}$ of 


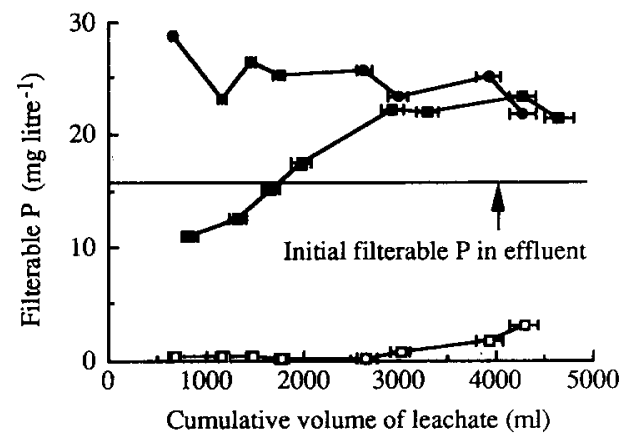

(a)

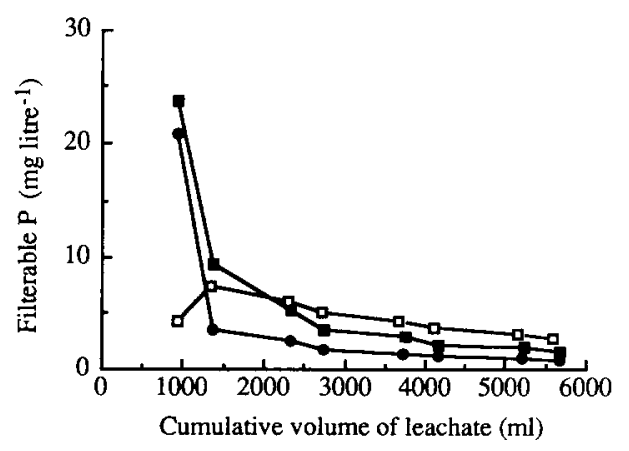

(b)

Fig. 1. Filterable $P\left(\mathrm{mg} \mathrm{litre} \mathrm{e}^{-1}\right)$ in the leachates of the $(O)$ Joel, (ם) Coolup, and ( $\square$ ) Balkuling soils as a function of cumulative leachate volume $(\mathrm{ml})$ after (a) leaching with struvite effluent, or (b) leaching with deionised water after treating the soil with struvite effluent. (Bars show standard errors.)

effluent had been applied. The rate of loss of $P$ from the Balkuling soil was always lower than the Joel and Coolup soils, but increased after more than $3000 \mathrm{ml}$ of effluent had been applied (Fig. 2(a)).

Phosphorus in leachates after treating soil with struvite effluent and deionised water

The amount of filterable $P$ in the leachates of soil columns pre-treated with struvite effluent and subsequently leached with deionised water followed the order Coolup $>$ Joel $>$ Balkuling (Fig. 2(b), Table 4). The Coolup and Joel soils lost a greater proportion of $\mathrm{P}$ retained during the previous leaching with effluent than the Balkuling soil (Table 4). Filterable P concentrations decreased rapidly during early stages of leaching for the

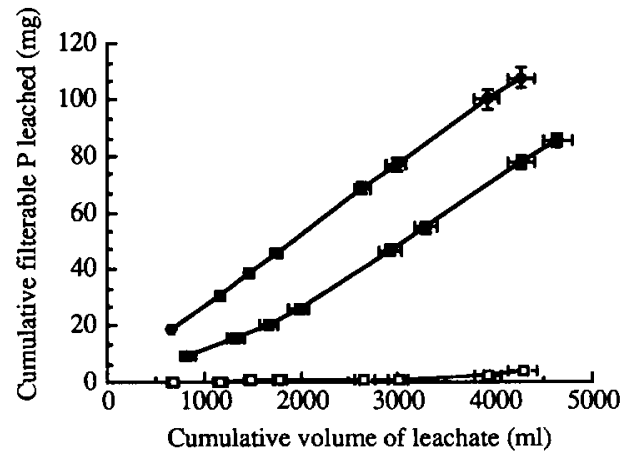

(a)

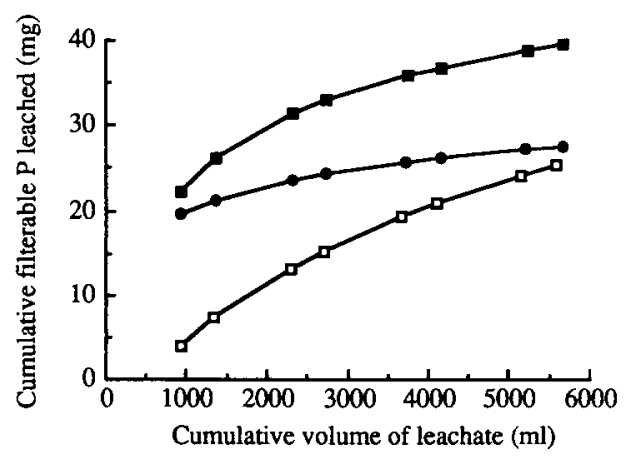

(b)

Fig. 2. Cumulative filterable $P$ leached $(\mathrm{mg})$ as a function of cumulative leachate volume $(\mathrm{ml})$ for the $(\mathbf{)}$ Joel, ( $\square$ ) Coolup, and $(\square)$ Balkuling soils after (a) leaching with struvite effluent, or (b) leaching with deionised water after treating the soil with struvite effluent. (Bars show standard errors.)

Joel and Coolup soils (Fig. 1(b)). Subsequently, the rate of decrease in filterable $P$ concentration was low, as was the rate of decrease in filterable $\mathbf{P}$ concentration for the Balkuling soil over the entire leaching event.

\section{Soil chemical changes after treatment with struvite effluent and deionised water}

When the soil was treated with struvite effluent, TP and inorganic soil $P$ increased mainly in the upper soil layers. Bicarbonate extractable $P$ increased in all layers of each soil (Table 5). The increase occurred mostly in the upper soil layers and the largest increase was for the Balkuling soil. The addition of effluent increased electrical conductivity (EC), $\mathrm{pH}$ and extractable filterable $\mathrm{P}$ (Tables 1 and 5).

Table 4. Phosphorus leached from or retained by soils treated with struvite effluent (leach 1) and subsequently leached with deionised water (leach 2)

\begin{tabular}{|c|c|c|c|c|c|c|}
\hline \multirow[t]{3}{*}{ Soil } & \multirow{3}{*}{$\begin{array}{c}\mathrm{TP} \\
\text { applied } \\
\left(\mathrm{mg} \mathrm{g}^{-1} \text { soil) }\right.\end{array}$} & \multicolumn{3}{|c|}{ Leach 1} & \multirow{3}{*}{$\begin{array}{l}\text { P retained } \\
\left(\mathrm{mg} \mathrm{g}^{-1} \text { soil }\right)\end{array}$} & \multirow{3}{*}{$\begin{array}{c}\text { Leach } 2 \\
\begin{array}{l}\mathrm{P} \text { leached } \\
\text { ( } \% \text { of } \mathrm{P}\end{array} \\
\text { retained in } \\
\text { leach } 1)\end{array}$} \\
\hline & & \multirow{2}{*}{$\begin{array}{c}\text { Filterable } P \\
\text { applied } \\
\left(\mathrm{mg} \mathrm{g}^{-1} \text { soil }\right)\end{array}$} & \multicolumn{2}{|c|}{ P leached } & & \\
\hline & & & $\begin{array}{l}(\% \text { of } \\
\text { applied } \\
\text { TP) }\end{array}$ & $\begin{array}{c}(\% \text { of } \\
\text { applied } \\
\text { filterable } \mathrm{P})\end{array}$ & & \\
\hline Joel & $0 \cdot 19$ & 0.08 & 62 & 159 & 0.07 & 41 \\
\hline Coolup & $0 \cdot 15$ & 0.06 & 46 & 116 & 0.08 & 40 \\
\hline Balkuling & $0 \cdot 19$ & 0.08 & 2 & 6 & $0 \cdot 19$ & 14 \\
\hline
\end{tabular}


Table 5. Some soil properties at each depth after leaching with struvite effluent (leach 1) and subsequently with deionised water (leach 2)

\begin{tabular}{|c|c|c|c|c|c|c|c|c|}
\hline \multirow[t]{2}{*}{ Soil } & \multirow[t]{2}{*}{$\begin{array}{l}\text { Depth } \\
(\mathrm{cm})\end{array}$} & \multirow[t]{2}{*}{$\begin{array}{c}\mathrm{EC} \\
\left(\mu \mathrm{S} \mathrm{cm}^{-1}\right)\end{array}$} & \multirow[t]{2}{*}{$\mathrm{pH}$} & $\begin{array}{c}\text { Filterable } \\
\text { P }\end{array}$ & $\begin{array}{c}\text { Bicarbonate } \\
\text { P }\end{array}$ & TP & $\begin{array}{c}\text { Inorganic } \\
\mathrm{P}\end{array}$ & $\underset{\mathbf{P}}{\text { Organic }}$ \\
\hline & & & & \multicolumn{5}{|c|}{$\left(\mu \mathrm{g} \mathrm{g}^{-1}\right)$} \\
\hline \multicolumn{9}{|l|}{ Leach 1} \\
\hline \multirow[t]{6}{*}{ Balkuling } & $0-1$ & 278 & $7 \cdot 5$ & 27 & 131 & 383 & 370 & 13 \\
\hline & $1-2$ & 255 & $7 \cdot 3$ & 18 & 108 & 301 & 251 & 50 \\
\hline & $2-4$ & 280 & $7 \cdot 3$ & 10 & 63 & 238 & 167 & 70 \\
\hline & $4-6$ & 256 & $7 \cdot 2$ & 7 & 54 & 194 & 108 & 86 \\
\hline & 6.8 & 224 & $7 \cdot 1$ & 4 & 28 & 162 & 70 & 92 \\
\hline & $8-10$ & 250 & $6 \cdot 9$ & 3 & 20 & 115 & 44 & 71 \\
\hline \multirow[t]{6}{*}{ Joel } & $0-1$ & 181 & $7 \cdot 1$ & 24 & 22 & 37 & 22 & 15 \\
\hline & $1-2$ & 159 & $6 \cdot 7$ & 12 & 13 & 28 & 12 & 16 \\
\hline & $2-4$ & 167 & $6 \cdot 8$ & 11 & 13 & 20 & 12 & 9 \\
\hline & $4-6$ & 153 & $6 \cdot 6$ & 9 & 9 & 21 & 10 & 11 \\
\hline & 68 & 154 & $6 \cdot 5$ & 9 & 11 & 20 & 9 & 11 \\
\hline & $8-10$ & 171 & $6 \cdot 4$ & 12 & 15 & 24 & 12 & 12 \\
\hline \multirow[t]{6}{*}{ Coolup } & $0-1$ & 82 & $7 \cdot 8$ & 11 & 32 & 56 & 38 & 18 \\
\hline & $1-2$ & 61 & $7 \cdot 5$ & 11 & 24 & 46 & 34 & 13 \\
\hline & $2-4$ & 54 & $7 \cdot 4$ & 9 & 25 & 48 & 29 & 19 \\
\hline & $4-6$ & 50 & $7 \cdot 3$ & 9 & 19 & 31 & 26 & 5 \\
\hline & $6-8$ & 52 & $7 \cdot 3$ & 9 & 19 & 32 & 28 & 4 \\
\hline & $8-10$ & 75 & $7 \cdot 1$ & 9 & 20 & 30 & 22 & 8 \\
\hline \multicolumn{9}{|l|}{ Leach 2} \\
\hline \multirow[t]{6}{*}{ Balkuling } & $0-1$ & 125 & $7 \cdot 3$ & 5 & 111 & 231 & 233 & 88 \\
\hline & $1-2$ & 131 & $7 \cdot 2$ & 5 & 77 & 277 & 241 & 35 \\
\hline & $2-4$ & 134 & $7 \cdot 3$ & 5 & 64 & 210 & 156 & 55 \\
\hline & $4-6$ & 146 & $7 \cdot 2$ & 3 & 49 & 193 & 114 & 79 \\
\hline & $6-8$ & 139 & $7 \cdot 1$ & 2 & 40 & 154 & 76 & 78 \\
\hline & $8-10$ & 135 & $7 \cdot 2$ & 2 & 28 & 117 & 55 & 62 \\
\hline \multirow[t]{6}{*}{ Joel } & $0-1$ & 74 & $7 \cdot 2$ & 4 & 4 & 11 & 4 & 6 \\
\hline & $1-2$ & 83 & $7 \cdot 1$ & 2 & 2 & 10 & 4 & 6 \\
\hline & $2-4$ & 85 & $7 \cdot 1$ & 2 & 2 & 10 & 4 & 6 \\
\hline & $4-6$ & 84 & $7 \cdot 1$ & 2 & 3 & 12 & 4 & 8 \\
\hline & $6-8$ & 82 & $6 \cdot 9$ & 2 & 3 & 12 & 4 & 8 \\
\hline & $8-10$ & 96 & 6.9 & 2 & 4 & 12 & 5 & 7 \\
\hline \multirow[t]{6}{*}{ Coolup } & $0-1$ & 32 & $7 \cdot 3$ & 4 & 18 & 37 & 38 & -1 \\
\hline & $1-2$ & 28 & $7 \cdot 1$ & 3 & 17 & 30 & 21 & 9 \\
\hline & $2-4$ & 24 & $7 \cdot 1$ & 2 & 12 & 25 & 15 & 9 \\
\hline & 46 & 26 & $7 \cdot 0$ & 2 & 10 & 19 & 12 & 8 \\
\hline & $6-8$ & 27 & $7 \cdot 0$ & 2 & 7 & 13 & 8 & 5 \\
\hline & $8-10$ & 30 & 7.0 & 2 & 7 & 15 & 7 & 8 \\
\hline
\end{tabular}

After leaching the treated soils with deionised water, EC, extractable filterable $P$, bicarbonate extractable $P$, TP, inorganic $\mathbf{P}$ and organic $\mathbf{P}$ generally decreased (Table 5). Inorganic $P$ in the Balkuling soil decreased in the upper soil layers and increased in the lower soil layers (Table 5).

Phosphorus in leachates after treating soil with recycled effluent without struvite

When the soils were treated with recycled effluent, the amount of total filterable $P$ found in the leachates was in the order Joel $>$ Coolup $\gg$ Balkuling (Fig. 3). Only $0.5 \%$ of the total $\mathrm{P}$ added to the Balkuling soil was found in the leachate whereas $68 \%$ was found in the leachate of the Joel soil (Table 6). The total filterable $\mathrm{P}$ in the leachate of the Joel soil was $86 \%$ of the total filterable $\mathbf{P}$ applied. In the Balkuling soil, however, only $0.7 \%$ of the applied total filterable $\mathrm{P}$ was found in the leachate (Table 6). The rate of loss of $P$ from the soils increased in the order Joel $>$ Coolup $\gg$ Balkuling. Total filterable $\mathrm{P}$ concentrations in the leachate were always equal to or less than the original $P$ concentrations applied. The rate of loss of $P$ from each soil was constant as leaching progressed, but was greater than when soils were leached with struvite effluent.

\section{Experiment 3-Leaching of $P$ from soils amended with} lime residues

For all three soils, $\mathrm{P}$ lost as filterable $\mathrm{P}$ from each $\mathrm{P}$ source followed the order superphosphate $>$ hydrated lime residue $>$ lime kiln dust residue $>$ no $\mathrm{P}$ applied (Fig. 4, Table 7). The difference between the amount of $P$ lost from superphosphate and the lime residue sources of $\mathbf{P}$ was greater for the Balkuling and Coolup soils than for the Joel soil.

As leaching progressed, the rate at which $\mathrm{P}$ leached from each soil decreased. For all treatments applied to the Joel soil the rate of loss of $P$ was constant and low 
Table 6. P leached from or retained by soil treated with recycled piggery effluent

\begin{tabular}{|c|c|c|c|c|c|}
\hline \multirow[t]{2}{*}{ Soil } & \multirow{2}{*}{$\begin{array}{c}\text { TP applied } \\
\text { (mg g }{ }^{-1} \text { soil) }\end{array}$} & \multirow{2}{*}{$\begin{array}{l}\text { Total filterable } \\
\mathrm{P} \text { applied } \\
\text { (mg g } \mathrm{g}^{-1} \text { soil) }\end{array}$} & \multicolumn{2}{|c|}{ P leached } & \multirow{2}{*}{$\begin{array}{l}\text { P retained } \\
\left(\mathrm{mg} \mathrm{g}^{-1} \text { soil }\right)\end{array}$} \\
\hline & & & $\begin{array}{c}\% \text { of applied } \\
\text { TP }\end{array}$ & $\begin{array}{c}\% \text { of applied } \\
\text { total filterable } \\
\text { P }\end{array}$ & \\
\hline Joel & $0 \cdot 36$ & $0 \cdot 29$ & 68 & 86 & $0 \cdot 11$ \\
\hline Coolup & $0 \cdot 28$ & $0 \cdot 18$ & 31 & 39 & $0 \cdot 20$ \\
\hline Balkuling & 0.29 & $0 \cdot 23$ & 0.5 & 0.7 & 0.29 \\
\hline
\end{tabular}

after $2000 \mathrm{ml}$ had been leached and therefore no further notable $P$ loss occurred. The rate of loss of $P$ from the Coolup and Balkuling soils was greater than from the Joel soil after $2000 \mathrm{ml}$ had been leached for the superphosphate treatment.

\section{DISCUSSION}

\section{Disposal of piggery effluent by application to soils}

Surface application of struvite effluent onto high $P$ sorbing soils did not necessarily increase the removal of $P$ from effluent (in comparison to low $P$ sorbing soil) at $\mathrm{pH}>7$. In addition, solid forms of $\mathrm{P}$ in the struvite effluent were converted into soluble inorganic $\mathrm{P}$ at low $\mathrm{pH}$. These potentially soluble inorganic forms of $\mathrm{P}$ contributed to $\mathrm{P}$ losses by leaching and could directly contaminate waterways. Phosphorus retained by soil treated with piggery effluent was subsequently leached by deionised water. Subsequent losses increased with decreasing soil $\mathrm{P}$ sorption capacity, but were also influenced by the amount of previously retained $P$.

The characteristics of the soil and the source and the quantity of $\mathrm{P}$ applied determined the extent of $\mathrm{P}$ leaching from, or retention by the soil. Phosphorus sorption capacity and $\mathrm{pH}$ were the major soil properties that affected the rate and amount of $P$ leached, whereas the important characteristics of the effluent were its $\mathrm{pH}$, and the concentration and forms of $\mathrm{P}$ in it. The effect of effluent characteristics were illustrated by the difference in behaviour between ortho-phosphate solutions and struvite effluent when mixed with soil. Solid inorganic forms of $\mathrm{P}$ (struvite) became soluble and hence potentially leachable at low $\mathrm{pH}$ or were sorbed after

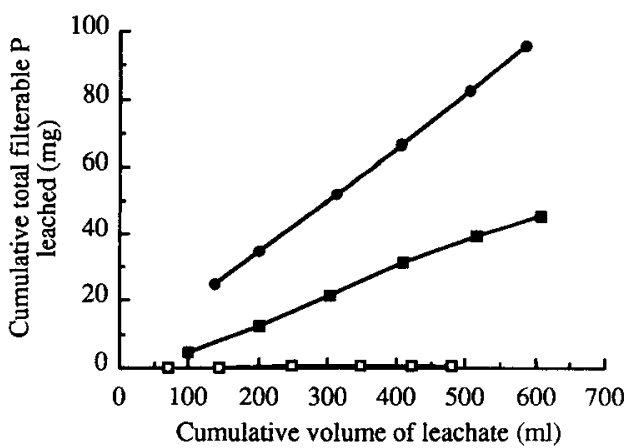

Fig. 3. Cumulative total filterable $P$ leached $(\mathrm{mg})$ as a function of cumulative leachate volume $(\mathrm{ml})$ for the $(\mathbf{O})$ Joel, $(\square)$ Coolup, and $(\square)$ Balkuling soils after leaching with recycled effluent (no struvite) dissolution if there were sufficient sorption sites. Hence, $P$ leaching became a function of the rate of application rather than effluent composition when soil properties caused complete dissolution of struvite.

The $\mathrm{pH}$ of each soil increased as the effluent: soil ratio increased. $\mathrm{pH}$ was important because it affected the dissolution of struvite in the effluent and the $P$ sorption capacity of the soils. The solubility of struvite increased as the $\mathrm{pH}$ decreased, whereas sorption of $\mathrm{P}$ decreased as $\mathrm{pH}$ increased.

The filterable $P$ lost from the Joel soil when it was treated with struvite effluent was far greater than the original filterable $\mathrm{P}$ concentration of the effluent would allow, presumably because the low $\mathrm{pH}$ of the soil dissolved struvite and thereby increased the filterable $\mathbf{P}$ concentration. The filterable $P$ loss only decreased at the high effluent: soil ratios because the $\mathrm{pH}$ was too high for complete struvite dissolution.

Phosphorus may have been desorbed from soil surfaces at alkaline $\mathrm{pH}$ and therefore could have contributed to the final filterable $\mathrm{P}$ concentration. In addition, competition between phosphate and organic anions from the piggery effluent may have led to an increase in the filterable $\mathrm{P}$ concentration at any $\mathrm{pH}$.

When soil was leached with water after treatment with struvite effluent, a large initial loss of $\mathbf{P}$ occurred because of the low strength with which it was held by the soil. Ensuing losses were much lower because the amount of $P$ retained by the soil from effluent was small. Nevertheless, the loss of $\mathrm{P}$ from leaching with deionised water was far smaller than that observed during leaching with effluent.

The $\mathrm{P}$ sorption capacity and phosphate retention index of the three soils increased in the order Joel < Coolup $\ll$ Balkuling and indicated one reason why the filterable $\mathrm{P}$ concentration of leachates for the three soils followed the order Joel $\gg$ Coolup $>$ Balkuling at the low effluent: soil ratios.

Table 7. $P$ leached (as a $\%$ of applied $P$ ) from the application of superphosphate or lime residues to different soils

\begin{tabular}{lcccc}
\hline Soil & $\begin{array}{c}\text { P applied } \\
\left(\mathrm{kg} \mathrm{ha}^{-1}\right)\end{array}$ & \multicolumn{4}{c}{ P source } \\
\cline { 3 - 5 } & & $\begin{array}{c}\text { Super- } \\
\text { phosphate }\end{array}$ & $\begin{array}{c}\text { Hydrated } \\
\text { lime residue }\end{array}$ & $\begin{array}{c}\text { Lime kiln } \\
\text { dust residue }\end{array}$ \\
\hline Joel & 10 & 92 & 60 & 50 \\
Coolup & 80 & 76 & 10 & $<1$ \\
Balkuling & 640 & 7 & $<1$ & $<1$
\end{tabular}




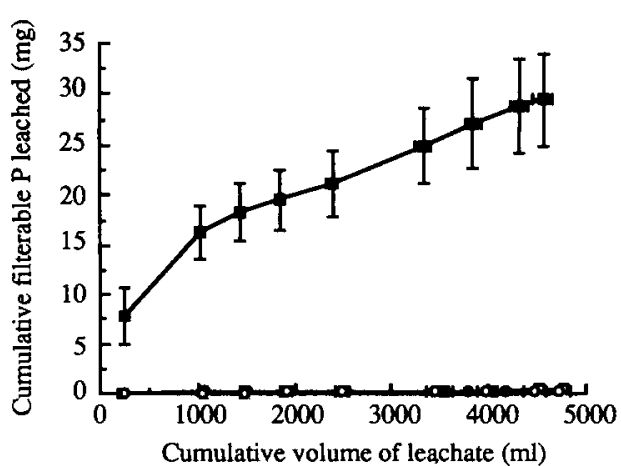

(a)

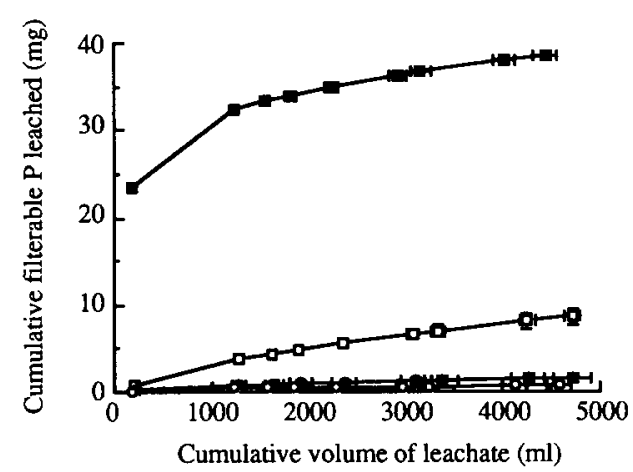

(b)

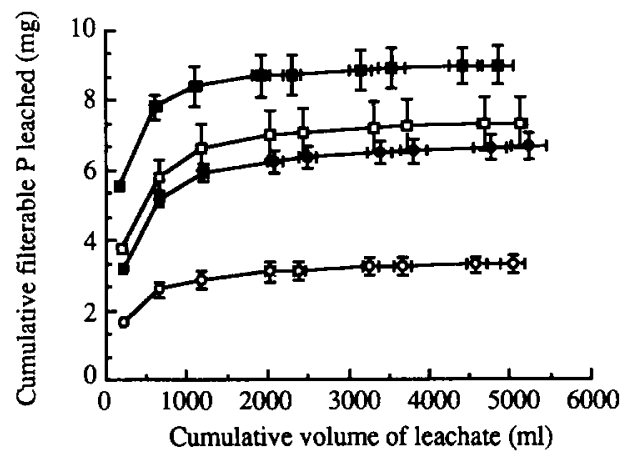

(c)

Fig. 4. Cumulative filterable $P$ leached $(\mathrm{mg})$ as a function of cumulative leachate volume $(\mathrm{ml})$ after the application of $(\bigcirc)$ no P, or $(\square) P$ as superphosphate, $(\square)$ hydrated lime residue, or (1) lime kiln dust residue for the (a) Balkuling,

(b) Coolup, and (c) Joel soils. (Bars show standard errors.)

The Balkuling soil had a high $\mathrm{P}$ sorption capacity and hence a low filterable $P$ loss at small effluent : soil ratios and low $\mathrm{pH}$ values. An increase in filterable $\mathbf{P}$ loss was observed as the effluent: soil ratio increased because of the concomitant increase in $\mathrm{pH}$ and $\mathrm{P}$ addition which decreased the number of sites for $\mathbf{P}$ sorption. Struvite dissolution could also have occurred, but the $P$ would have been sorbed as soon as it was released into solution.

The $\mathrm{P}$ sorption capacity of the Coolup soil, and how it was affected by $\mathrm{pH}$, were probably the main factors controlling the filterable $\mathrm{P}$ concentration after mixing effluent with that soil. Struvite dissolution would have been less than in the Joel soil because the $\mathrm{pH}$ of the soil was higher. The Coolup soil also has a higher $\mathrm{P}$ sorption capacity and hence less $P$ leached from it than the Joel soil after treatment with low volumes of effluent. As the effluent quantity increased, the concentration of $P$ in the leachate increased to a plateau. Presumably the concomitant increase in $\mathrm{pH}$ was lowering the number of sites available for sorption of $\mathbf{P}$. Some transformation of undissolved $\mathrm{P}$ must also have occurred because the filterable $\mathrm{P}$ concentration in the leachate was higher than that of the original effluent when $>2000 \mathrm{ml}$ of effluent had been applied. After leaching the soil with deionised water, the initial losses of $P$ in leachate were greater than those observed for the Joel soil. As more deionised water was added to the soil $(>2000 \mathrm{ml})$, the rate at which $\mathrm{P}$ was lost decreased presumably because it was retained more strongly than in the Joel soil.

The rate at which $P$ leached from the Joel soil was constant over the entire effluent leaching period (Figs 2(a) and 3). The rate of loss of $P$ from the Coolup soil was constant after more than $2000 \mathrm{ml}$ of struvite effluent had been applied suggesting the soils $\mathbf{P}$ sorption capacity was saturated at this point. The conditions for saturation of the $\mathrm{P}$ sorption capacity would be affected by factors such as $\mathrm{pH}$ because the effluent would be constantly increasing the soil $\mathrm{pH}$, particularly in the surface layers where struvite dissolution would normally take place. Struvite would no longer dissolve on contact with the soil when the $\mathrm{pH}$ became too high for dissolution (Table 3). As a result, the rate of loss of $P$ from the Joel and Coolup soils would be equivalent to the rate of application of filterable $\mathrm{P}$ when the $\mathrm{P}$ sorption capacity was saturated and the $\mathrm{pH}$ became too high for struvite dissolution. The rate of $\mathrm{P}$ loss from the Balkuling soil was lower because of the soils greater capacity to adsorb $P$. The rate of loss did increase, however, as more effluent was added and, if sufficient effluent was applied, the rate of loss would equal that of the Joel and Coolup soils under the same conditions described above. The rate of loss of $P$ from each soil was greater for recycled effluent than struvite effluent, presumably because the $\mathrm{P}$ concentration in the former was much greater than the latter and because much smaller quantities of effluent were applied to leach similar quantities of P. Excessive application of struvite effluent or recycled effluent to soil would lead to a leaching loss of $P$ equivalent to the application of filterable $P$. The $P$ sorption capacity of the soil is a major factor in determining when this occurs.

Phosphorus remaining in the soil after leaching with piggery effluent was inorganic in nature and its distribution down the soil columns depended on the P sorption capacity of the soil. The majority of $P$ in each soil was retained in the top $4 \mathrm{~cm}$ of each column. These results are similar to those of Jeffery and Uren (1979) and Unwin (1980) who showed that most $P$ applied in piggery effluent was retained in surface soil layers, although some leaching was observed down to $30 \mathrm{~cm}$ depth. This is probably because effluent is irrigated at high rates over a small area due to the time and cost associated with dispersal over larger areas. Vetter and Steffens (1980) showed an increased downward displacement of $\mathbf{P}$ when large amounts of slurry were 
applied and when slurry was applied to $\mathbf{P}$ enriched soils. Up to $13 \%$ of applied $\mathrm{P}$ ( $400 \mathrm{~kg} \mathrm{ha}^{-1}$ ) moved to soil depths of $60-90 \mathrm{~cm}$. The downward displacement of $\mathbf{P}$ occurred mainly on acid soils with low clay content, similar to the soils used in these experiments. Downward displacement of previously applied $\mathbf{P}$ was evident for the Balkuling soil. Bicarbonate extractable $P$ decreased in surface layers and increased at depth after leaching struvite effluent pre-treated soil with water (Table 5).

Other workers (Bhat \& O'Callaghan, 1980) have suggested that more of the ortho-phosphate in piggery effluent is sorbed by soil than from ortho-phosphate solutions and have implied that piggery effluent is less likely to cause direct groundwater pollution than conventional fertilizers. Our experiments suggest that these sources of $P$ would equally contribute to $P$ losses when applied to similar soils at the same $P$ rate. There are also other components of piggery effluent, such as dissolved high-molecular-weight organic $\mathrm{P}$, that are potentially mobile in soils (Gerritse \& Vriesema, 1984).

\section{Phosphorus losses from soils amended with lime residues from effluent treatment}

Phosphorus losses from soils amended with hydrated lime and kiln dust residues were much smaller than losses from soils amended with superphosphate. Other workers (Willett et al., 1984) showed little P loss occurred when lime treated sewage sludges were applied to soils.

The amount of filterable $\mathbf{P}$ in the leachates depended on the $\mathrm{P}$ source, $\mathrm{P}$ rate, $\mathrm{pH}$ and the $\mathrm{P}$ sorption capacity of the soil. For superphosphate and both lime residues, more $\mathrm{P}$ was lost from a $\mathrm{P}$ application of $80 \mathrm{~kg} \mathrm{ha}^{-1}$ to the Coolup soil than from the $640 \mathrm{~kg} \mathrm{ha}^{-1}$ application to the Balkuling soil, because the latter soil has a much greater $\mathrm{P}$ sorption capacity than the Coolup soil (Fig. 4, Tables 1 and 7). The rate of loss of $P$ from the Joel soil was initially rapid and then very low for all treatments. This is probably because of the low sorption capacity of the Joel soil and the low $\mathrm{P}$ application rate. Phosphorus continued to be lost at a greater rate from the Coolup and Balkuling soils than the Joel soil when more than $2000 \mathrm{ml}$ had been leached for the superphosphate treatment, because of greater $\mathrm{P}$ application rate and sorption capacity of these soils (Fig. 4).

The Joel soil has a lower $\mathrm{pH}$ than the Coolup and Balkuling soils which would favour the dissolution of $\mathbf{P}$ from the lime residues in the Joel soil. Therefore the difference between the $\mathbf{P}$ lost from superphosphate compared to the lime residues was lower in the Joel soil than the other two soils. In addition, the $\mathrm{pH}$ would be increased by the addition of the lime residue to a greater extent in the Coolup and Balkuling soils because of the higher $\mathbf{P}$ application rate and hence the higher application of residue. The increased $\mathrm{pH}$ may enhance the precipitation of $\mathbf{P}$ due to the presence of calcium and magnesium and their carbonates, both of which are constituents of the source lime materials used to precipitate $\mathrm{P}$ from piggery effluent (Weaver \& Ritchie, 1987). Neutralising value further complicates $P$ sorption and $\mathrm{P}$ loss because changes in $\mathrm{pH}$ affect phosphate species and surface charge independently.

The smaller loss of $\mathrm{P}$ from the application of lime kiln dust residues compared with hydrated lime residues applied to the Joel and Coolup soils was probably because of the higher application of a residue with a low $\mathrm{P}$ content and higher neutralising value. A much smaller amount of water soluble $\mathbf{P}$ was applied in the lime kiln dust residues along with a greater quantity of material with a higher neutralising value. A higher $\mathrm{pH}$ may have resulted, further restricting the dissolution of $\mathbf{P}$ from the lime kiln dust residue.

\section{REFERENCES}

Allen, D. G. \& Jeffery, R. C. (1990). Methods for analysis of phosphorus in Western Australian soils. Report of Investigation No. 37, Agricultural Chemistry Laboratory, Chemistry Centre of Western Australia, Australia.

AOAC (1984). Methods of Analysis (12th edn). Association of Official Analytical Chemists, Washington DC, USA.

Bettenay, E., McArthur, W. M. \& Hingston, F. J. (1960). The soil associations of part of the Swan Coastal Plain, Western Australia. CSIRO, Aust. Soils and Land Use Series, No. 35, CSIRO, Canberra, ACT, Australia.

Bhat, K. S. \& O'Callaghan, J. R. (1980). Behaviour in the soil of orthophosphate from pig slurry compared with that of $\mathrm{KH}_{2} \mathrm{PO}_{4}$. J. Agric. Sci. Camb., 94, 195-201.

Colwell, J. D. (1963). The estimation of phosphorus fertilizer requirements of wheat in southern New South Wales by soil analysis. Aust. J. Exper. Anim. Husb., 3, 190-7.

Gerritse, R. G. \& Vriesema, R. (1984). Phosphate distribution in animal waste slurries. J. Agric. Sci. Camb., 102, 159-61.

Hanson, W.C. (1950). The photometric determination of phosphorus in fertilizers using the phosphovanadomolybdate complex. J. Sci. Food Agric., 1, 172.

Humphries, R. \& Bott, G. M. (1987). Intensive animal industries on the Swan Coastal Plain, and their associated pollution problems. In Proceedings of 'The Swan Coastal Plain in Crisis-Agriculture and the Environment', (Occasional Publication No. 10) Australian Institute of Agricultural Science (WA), pp. 59-68.

Jeffery, J. J. \& Uren, N.C. (1979). The effect of the application of piggery effluent to soils and pastures. Prog. Water Technol., 11, 275-82.

John, M. K. (1970). Colorimetric determination of phosphorus in soil and plant materials with ascorbic acid. Soil Sci., 109, 214-20.

Mulcahy, M. J. (1960). Laterites and lateritic soils in southwestern Australia. J. Soil Sci., 11, 206-25.

Northcote, K. H. (1979). A Factual Key for the Recognition of Australian Soils. Rellim Technical Publications, Adelaide, South Australia, Australia.

Payne, R. W. (1986). Characteristics of faeces from institutional and commercial piggeries. Agric. Wastes, 16, 1-11.

Raper, W. G. C. (1983). Water pollution-sewage-recycling. In Phosphorus in Australia, ed. A. B. Costin \& C. H Williams. Centre for Resource and Environmental Studies, Australian National University, Canberra, ACT, Australia.

Sas, H. (1989). Lake Restoration by Reduction of Nutrient Loading, ed. H. Sas. Academia Verlag Richarz PublikationsService, 5205 Sankt Augustin 1, Austria.

Saunders, W. M. H. \& Williams, E. G. (1955). Observations on the determination of total and organic phosphorus in soils. J. Soil Sci., 6, 248-67.

Searle, P. L. \& Daly, B. K. (1977). The determination of Al, $\mathrm{Fe}, \mathrm{Mn}$ and $\mathrm{Si}$ in acid oxalate soil extracts by flame emission and atomic absorption spectrometry. Geoderma, 19, 1-10. 
Sims, J. R. \& Haby, V. A. (1971). Simplified colorimetric determination of soil organic matter. Soil Sci., 112, 137-41.

Thomas, G. W. (1982). Exchangeable cations. In Methods of Soil Analysis (Part 2), Chemical and Microbiological Properties, 2nd edn, ed. A. L. Page, R. H. Miller \& D. R. Keeney, American Society of Agronomy Inc. and Soil Science Society of America, Madison, USA, pp. 159-65.

Unwin, R. J. (1980). Phosphorus accumulation and mobility from large applications of slurry. In Phosphorus in Sewage Sludge and Animal Waste Slurries, ed. T. W. G. Hucker \& G. Catroux. Reidel Publishing Company, Dordrecht, The Netherlands, pp. 333-43

Vetter, H. \& Steffens, G. (1980). Phosphorus accumulation in soil profiles and phosphorus losses after the application of animal manures. In Phosphorus in Sewage Sludge and Animal
Waste Slurries, ed. T. W. G. Hucker \& G. Catroux. Reidel Publishing Company, Dordrecht, The Netherlands, pp. 309-27. Weaver, D. M. \& Ritchie, G. S. P. (1987). The effectiveness of lime-based amendments and bauxite residues at removing phosphorus from piggery effluent. Environ. Pollut., 46, $163-75$.

Weaver, D. M. \& Ritchie, G. S. P. (1994). Phosphorus removal from piggery effluents of varying quality using lime and physico-chemical treatment methods. Environ. Pollut., 84, 235-42.

Willett, I. R., Jakobsen, P., Malafant, K. W. J. \& Bond, W. J. (1984). Effects of land disposal of lime treated sewage sludge on soil properties and plant growth, report for 1982-83. CSIRO, Australia, Division Water and Land Resources, Divisional Report 84/3, Canberra, ACT, Australia. 